\title{
CHROMATOGRAPHY OF SERUM PROTEINS IN NORMAL AND PATHOLOGIC SERA: THE DISTRIBUTION OF PROTEIN-BOUND CARBOHYDRATE AND CHOLESTEROL, SIDEROPHILIN, THYROXIN-BINDING PROTEIN, $\mathrm{B}_{12}$-BINDING PROTEIN, ALKALINE

By JOHN L. FAHEY, PATRICIA F. McCOY, AND MEHRAN GOULIAN

(From the Metabolism Service, National Cancer Institute, National Institutes of Health, Public Health Service, Department of Health, Education and Welfare, Bethesda, Md.)

(Submitted for publication August 24, 1957; accepted September 26, 1957)

Chromatographic techniques have recently been introduced which provide new approaches to serum protein separation and characterization (1-4). Sober, Gutter, Wyckoff, and Peterson, using diethylaminoethyl (DEAE) cellulose, described the initial application of anion-exchange cellulose chromatography to the fractionation and identification of serum proteins $(1,2)$. Their study indicated the great potential usefulness of anion-exchange cellulose chromatography for the study of proteins, but considerable time and work was required to carry out a single determination.

The system of analysis employed in these studies was adapted from a technique developed during a continuing investigation by Drs. Peterson and Sober (5) of chromatographic methods for protein separation. It differs from the technique described previously (2) principally in the use of a single gradient elution system and in modifications introduced in the present study for the purpose of decreasing the initial loss of euglobulins and reducing the time and work involved. These modifications made feasible the chromatographic examination of multiple individual serum samples and serum fractions. Serum samples of 20, 10, 2 , and $1 \mathrm{ml}$. have been examined by this method.

The present study reports the initial findings in the application of the modified chromatographic procedure to the examination of normal human serum and serum obtained in various diseases. The chromatographic fractions of normal serum were characterized by electrophoresis and by carbohydrate and cholesterol content. The chromatographic behavior of siderophilin (iron-binding protein, transferrin), vitamin $\mathrm{B}_{12}$-binding protein, thyroxin-binding protein, alkaline and acid phos- phatases, myeloma protein and radioiodinated human serum albumin was also determined.

\section{METHODS}

Sample. Early morning fasting blood samples were obtained and allowed to clot at room temperature for about four hours. Serum was removed after centrifugation, and dialysis was started immediately or the sample was frozen for future analysis. The serum to be chromatographed was dialyzed at $4^{\circ} \mathrm{C}$. for six or more hours with internal stirring against at least three changes of 15 to 30 volumes each of $\mathrm{pH} 8$ sodium phosphate buffer that was $0.01 \mathrm{M}$ for phosphate. After dialysis, a small amount of white flocculant precipitate, comprising 0.5 to 3 per cent of the total serum protein was separated by centrifugation at 2 to $4^{\circ} \mathrm{C}$. The volume of the clear amber supernatant serum was measured and an aliquot was set aside for analytic purposes.

Column preparation. Anion-exchange cellulose adsorbent, DEAE-SF, which had been prepared as a single large batch, was used throughout these studies. ${ }^{1}$ After each chromatogram was completed, the adsorbent was regenerated (1), employing the following sequence of washes: $0.3 \mathrm{M}$ monosodium phosphate, $0.5 \mathrm{~N}$ sodium hydroxide alternating with water, acidified alcohol to remove nonsaponifiable lipid, and finally alkali and water washes prior to adjustment of the adsorbent to $\mathrm{pH} 8$. The adsorbent was then rinsed with at least $1 \mathrm{~L}$. of $0.01 \mathrm{M} \mathrm{pH} 8$ sodium phosphate buffer. A dilute suspension of the adsorbent was added to a $2.5 \mathrm{~cm}$. O.D. pyrex column and packed with the aid of air pressure (gradually increased to 10 p.s.i. to maintain an effluent flow of $1 \mathrm{ml}$. per 15 to 30 seconds), then transferred to a cold room $\left(4^{\circ} \mathrm{C}\right.$.) and washed further with buffer. Approximately

1 Solka-Floc SW-40B was sieved to obtain a 230 to 325 mesh fraction that was used as the starting material in preparation of the DEAE-cellulose, which was generously made available by Drs. E. A. Peterson and H. A. Suber. This preparation contained 1.34 per cent nitrogen (0.96 mEq. per Gm.). 
TABLE I

Conditions employed for chromatography of a range of serum volumes

\begin{tabular}{|c|c|c|c|c|c|c|c|}
\hline \multirow[b]{2}{*}{$\begin{array}{l}\text { Adsorbent } \\
(G m .)\end{array}$} & \multirow{2}{*}{$\begin{array}{c}\text { Serum } \\
\text { sample } \\
(m l .)\end{array}$} & \multicolumn{3}{|c|}{$\underset{(\mathrm{cm} .)}{\text { Column size }}$} & \multirow[b]{2}{*}{$\begin{array}{l}\text { Round } \\
\text { flask* }\end{array}$} & \multirow[b]{2}{*}{$\begin{array}{l}\text { Erlenmeyer } \\
\text { flask } 千\end{array}$} & \multirow[b]{2}{*}{$\begin{array}{c}\text { Flow rate } \\
(m l . / h r .)\end{array}$} \\
\hline & & $\begin{array}{l}\text { Adsorbent } \\
\text { length }\end{array}$ & $x$ & $\begin{array}{l}\text { O. D. } \\
\text { of tube }\end{array}$ & & & \\
\hline 16 & 20 & 36.5 & $x$ & 2.5 & 1,000 & 500 & $20-25$ \\
\hline 9 & 10 & 21 & $x$ & 2.5 & 500 & 250 & $15-20$ \\
\hline \multirow[t]{2}{*}{3} & 2 & 29 & $x$ & 1.4 & 250 & 125 & 10 \\
\hline & 1 & 27 & $x$ & 1.2 & $\begin{array}{l}110 \\
110\end{array}$ & $\begin{array}{l}55 \\
55\end{array}$ & $\begin{array}{l}10 \\
10\end{array}$ \\
\hline
\end{tabular}

* Size of flask and volume (ml.) of $0.01 \mathrm{M} \mathrm{pH} 8$ phosphate buffer.

† Size of flask and volume (ml.) of $0.30 \mathrm{M}$ monosodium phosphate.

$16 \mathrm{Gm}$. of adsorbent was used to prepare columns packed $36 \mathrm{~cm}$. high.

Development of the chromatogram. Elution of proteins was accomplished by a system which produced a continuous rise in phosphate molarity from 0.01 to $0.30 \mathrm{M}$ and a fall in $\mathrm{pH}$ from 8.0 to 4.5 in the buffer entering the column. This was achieved by the apparatus (5) illustrated in Figure 1, which consisted of a cone-shaped reservoir (Erlenmeyer flask) filled with $0.3 \mathrm{M}$ monosodium phosphate connected by a syphon to a spherical mixing chamber (round bottom flask) filled with $0.01 \mathrm{M} \mathrm{pH} 8$ sodium phosphate buffer. The syphon and tubing leading to the column were filled with this latter buffer. Dialyzed serum was applied to the column as previously described (2), and continuous buffer flow from the gradient elution apparatus was started. With the $16 \mathrm{Gm}$. adsorbent columns a flow rate of approximately 20 to $25 \mathrm{ml}$. per hour was achieved with the flasks 32 inches above the top of the adsorbent column. Effluent fractions of $4 \mathrm{ml}$. or $8 \mathrm{ml}$. were collected in an automatic fraction collector ${ }^{2}$ from the time of introduction of serum onto the adsorbent.

For smaller serum samples (or equivalent amounts of protein) the equipment was modified as outlined in Table I. The relative ratio of the capacity of the round bottom and the Erlenmeyer flasks was kept at 2:1. In the smaller chromatograms $3 \mathrm{ml}$. fractions were generally collected.

Examination of the effluent. The effluent fractions were routinely examined for protein content in a Beckman DU spectrophotometer by measuring the optical density at $280 \mathrm{~m} \mu$. Biuret determination of the total protein in serum was made by the method of Gornall, Bardawill, and David (6). Dilute solutions were tested by the modification described by Lever and co-workers (7). Each series of biuret readings was standardized against a preparation of crystalline bovine serum albumin which had been checked by a micro-Kjeldahl method. $\mathrm{pH}$ measurements were made at room temperature. Ultrafiltration, when required, was carried out at $4^{\circ} \mathrm{C}$. (2).

Paper electrophoretic determinations were made on $0.008 \mathrm{ml}$. of whole serum or 0.01 to $0.05 \mathrm{ml}$. of concentrated effluent (usually 0.1 to $0.5 \mathrm{mg}$. protein). Eight

\footnotetext{
${ }^{2}$ Gilson Medical Electronics, Inc., Madison, Wisconsin.
}

2.9 by $30.0 \mathrm{~cm}$. Whatman $3 \mathrm{MM}$ filter paper strips moistened with $0.075 \mu \mathrm{pH} 8.6$ diethyl barbiturate buffer were run simultaneously in one cell of the hanging strip type (8) at room temperature for 18 hours at a constant current of $6 \mathrm{ma}$. per cell and under a potential of 68 to 72 volts. The strips were stained with bromphenol blue (9) and evaluated by transmission densitometry with an integrating scanner, ${ }^{3}$ using a cam which provided a plot linear with sample concentration. In each electrophoretic cell a normal human serum was utilized as a standard on at least one paper strip. Electrophoretic identification of components on other strips was made relative to the movement of the components in this standard. In order to better detect and quantify components present in small amounts, a crystalline bovine albumin "carpet" $(0.01 \mathrm{ml}$. of a 3 per cent solution) was applied and subjected to

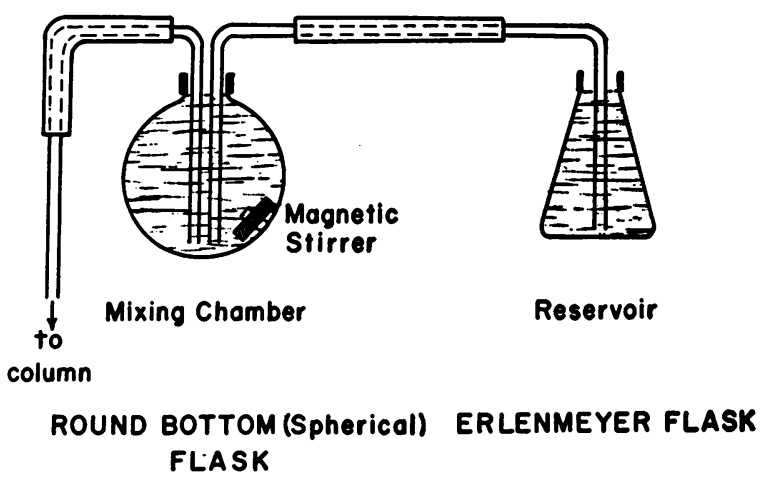

Fig. 1. Diagram of the Mixing-Chamber and

ReservoIr Utilized During Chromatography

At the beginning of the chromatographic procedure the round bottom flask is filled with $0.01 \mathrm{M} \mathrm{pH} 8$ phosphate buffer and the Erlenmeyer flask with $0.3 \mathrm{M}$ monosodium phosphate in a ratio of $2: 1$, respectively. The fluid level was the same in each flask. A small notch (not illustrated) is present at the orifice of each glass tube in the mixing chamber and reservoir and serves to prevent sealing and facilitate mixing.

${ }^{3}$ Analytrol (R), Spinco Division, Beckman Instruments, Inc., Belmont, California. 
electrophoresis for five hours prior to application of the fractions to be analyzed.

Localization of specific properties. Serum to be examined was prepared as described above and a standard chromatographic procedure was employed, utilizing about $20 \mathrm{ml}$. of serum, $16 \mathrm{Gm}$. of adsorbent, a flow rate of 20 to $25 \mathrm{ml}$. per hour, effluent collected in $4 \mathrm{ml}$. fractions, and gradient elution with $1,000 \mathrm{ml}$. of $0.01 \mathrm{M} \mathrm{pH} 8$ sodium phosphate in the round bottom flask and $500 \mathrm{ml}$. of $0.30 \mathrm{M}$ monosodium phosphate in the Erlenmeyer flask. This procedure was altered only in the study of thyroxinbinding protein as described below.

Protein-bound carbohydrate distribution was assessed by a modification of the thymol-sulfuric acid method of Shetlar and Masters (10). The results expressed here are considered to represent protein-bound hexose. Serums to be tested for glycoprotein distribution were dialyzed against an extra two changes of buffer to assure the removal of free sugar.

Cholesterol measurements were made according to the method of Abell, Levy, Brodie, and Kendall (11). Aliquots of the effluent fractions were pooled so that the chromatogram was divided equally among , 40 fractions. These pools were then lyophilized to reduce the volume prior to cholesterol analysis.

Siderophilin (iron-binding protein, transferrin) was located by means of tracer amounts of radioactive iron. To $25 \mathrm{ml}$. of fresh normal serum, which contained $73 \mu \mathrm{g}$. per cent iron and $300 \mu \mathrm{g}$. per cent total iron binding capacity (12), was added $24 \mu \mathrm{g}$. $(25 \mu \mathrm{c}$.) of iron as ferric chloride. Unlabeled ferric chloride was then added to assure saturation of the serum iron-binding capacity. Twenty $\mathrm{ml}$. of the dialyzed serum was added to the adsorbent column and chromatography was carried out in the usual way. Radioactivity in the effluent fractions was determined in a well-type scintillation counter. About 30 per cent of the radioactivity was recovered in the eluate. The remaining radioactive iron, having become separated from the protein and bound to the adsorbent during chromatography, was later removed from the adsorbent and found to be dialyzable.

The vitamin $\mathrm{B}_{12}$-binding protein was identified by means of $B_{12}$ assays utilizing $L$. leichmanii ATCC 4797 in a modification of the standard U.S.P. procedure (13).

Serum with high acid or alkaline phosphatase activity was obtained from patients with metastatic neoplasms. The whole serum and individual fractions were assayed for alkaline and acid phosphatase activity by adaptations of the method of Bessey, Lowry, and Brock (14). Phosphate was removed from the chromatographic fractions prior to acid phosphatase analysis by thorough dialysis against $\mathrm{pH} 5,0.15 \mathrm{M}$ sodium acetate buffer and prior to alkaline phosphatase analysis by dialysis against a $0.05 \mathrm{M}$ sodium acetate: $0.10 \mathrm{M}$ sodium chloride solution. The alkaline and acid phosphatase recoveries in these chromatograms were 125 and 91 per cent, respectively.

Thyroxin-binding protein was located by utilization of radioiodine-labeled thyroxin of at least 90 per cent purity. Normal serum $(20 \mathrm{ml}$.) mixed with $6.2 \mu \mathrm{g}$. of la- beled thyroxin was allowed to equilibrate overnight in the refrigerator before dialysis. Serum chromatography differed from the usual procedure in the use of a $750 \mathrm{ml}$. Erlenmeyer reservoir containing $0.3 \mathrm{M}$ monosodium phosphate and a beaker $10 \mathrm{~cm}$. in diameter containing $1 \mathrm{~L}$. of $0.01 \mathrm{M} \mathrm{pH} 7.5$ phosphate buffer as the mixing chamber. Effluent fractions of $6 \mathrm{ml}$. were collected, and the radioactivity was determined in $4 \mathrm{ml}$. aliquots by means of a well-type scintillation counter.

The electrophoretic localization of the radioactive thyroxin in the chromatographic fractions was ascertained by standard electrophoretic procedures and by reverseflow zone electrophoresis (15). After the strips were dried, radioactivity was measured with an end window Geiger-Müller counter, employing a continuously recording counting-rate meter (15), and the distribution of radioactivity was compared with protein distribution as determined by bromphenol blue staining.

The distribution of radioiodine-labeled albumin 4 was determined by addition of $0.1 \mathrm{ml}$. of solution containing $1.0 \mathrm{mg}$. $(20 \mu \mathrm{c}$.) of albumin to $27 \mathrm{ml}$. of fresh normal serum with a total protein concentration of $6.6 \mathrm{Gm}$. per cent of which 54.5 per cent was albumin on electrophoretic examination. After dialysis $20 \mathrm{ml}$. of serum was chromatographed. The radioactivity of the serum and chromatographic fractions was determined in a well-type scintillation counter and results were corrected for decay. The radioactivity recovered following chromatography was 91 per cent of the amount applied to the column.

\section{RESULTS}

\section{Normal serum chromatogram}

Chromatographic analysis has been performed as described above on 23 individual serums (20 ml. samples) from normal adults and also on 14 serums from patients representing a variety of diseases. A representative normal chromatogram is reproduced in Figure 2. A number of peaks of protein distribution are evident.

Electrophoretic characterization of the chromatogram (Figure 2) indicates that the usual electrophoretic components of serum have been subdivided by the chromatographic procedure. Also, it is apparent that most of the chromatographic regions are composed of several electrophoretically separable components.

Recovery of protein from the chromatogram was essentially complete. Table II compares the recovery of electrophoretic components in the

\footnotetext{
4 RISA was obtained from the Abbott Laboratories, North Chicago, Illinois, and is described by the manufacturers as containing 1 iodine: 51/2 molecules of albumin, less than 0.5 per cent dialyzable radioactivity, and as being homogeneous by electrophoretic analysis.
} 
TABLE II

Recovery of serum electrophoretic components in the chromatogram effluent

\begin{tabular}{|c|c|c|c|}
\hline Component & & $\begin{array}{l}\text { Chromato- } \\
\text { gram* } \\
\text { protein } \\
(\%)\end{array}$ & $\begin{array}{l}\text { Electro-- } \\
\text { phoretic† } \\
\text { protein } \\
(\%)\end{array}$ \\
\hline $\begin{array}{l}\text { Faster-than-albumin } \\
\text { Albumin } \\
\text { Alpha }\end{array}$ & & $\begin{array}{c}0.17 \\
60.3 \\
3.0\end{array}$ & $\begin{array}{r}58 \\
3\end{array}$ \\
\hline $\begin{array}{l}\text { Alpha } \\
\text { Alpha } \\
\text { Alpha }\end{array}$ & $\left.\begin{array}{l}2.0 \\
5.6 \\
0.8\end{array}\right\}$ & 7.6 & 7 \\
\hline $\begin{array}{l}\text { Beta } \\
\text { Gamma (very fast) }\end{array}$ & $\left.\begin{array}{l}7.4 \\
4.2\end{array}\right\}$ & 12.4 & 13 \\
\hline $\begin{array}{l}\text { Gamma (fast) } \\
\text { Gamma }\end{array}$ & $\left.\begin{array}{r}1.9 \\
14.6\end{array}\right\}$ & 16.5 & 19 \\
\hline
\end{tabular}

* Electrophoretic distribution of chromatographic components as illustrated in Figure 2.

† Whole serum electrophoretic analysis.

chromatogram illustrated in Figure 2 with the results of whole serum analysis. Good agreement is evident, suggesting that no major change in electrophoretic properties was produced by exposure of the serum proteins to the chromatographic procedure.

The sequence of serum protein elution is similar to that reported previously with a more complex procedure (2). Gamma globulins are the first proteins to appear in the effluent fractions. A high peak containing most of the gamma globulin is seen early in the chromatogram. However, gamma globulins continue to be removed from the column in succeeding fractions and are characterized by a gradually increasing electrophoretic mobility (Figure 3 ). Finally a small amount of gamma globulin of low mobility is seen again in the latter portion of the chromatogram. The progressive elution of electrophoretically faster-moving proteins extending into the "slow beta" electrophoretic region emphasizes the existence of a spectrum of electrical properties among the proteins in the gamma globulin region.

The beta globulins are divided into at least three components by the chromatographic procedure, and the alpha globulins are divided into at least seven components (Figure 2).

Albumin emerges approximately midway through the elution procedure. The major portion of the albumin is obtained in a relatively narrow portion of the effluent volume. However, albumin continues to be eluted from the column in progressively decreasing amounts.
NORMAL SERUM CHROMATOGRAM: Electrophoretic Compodition

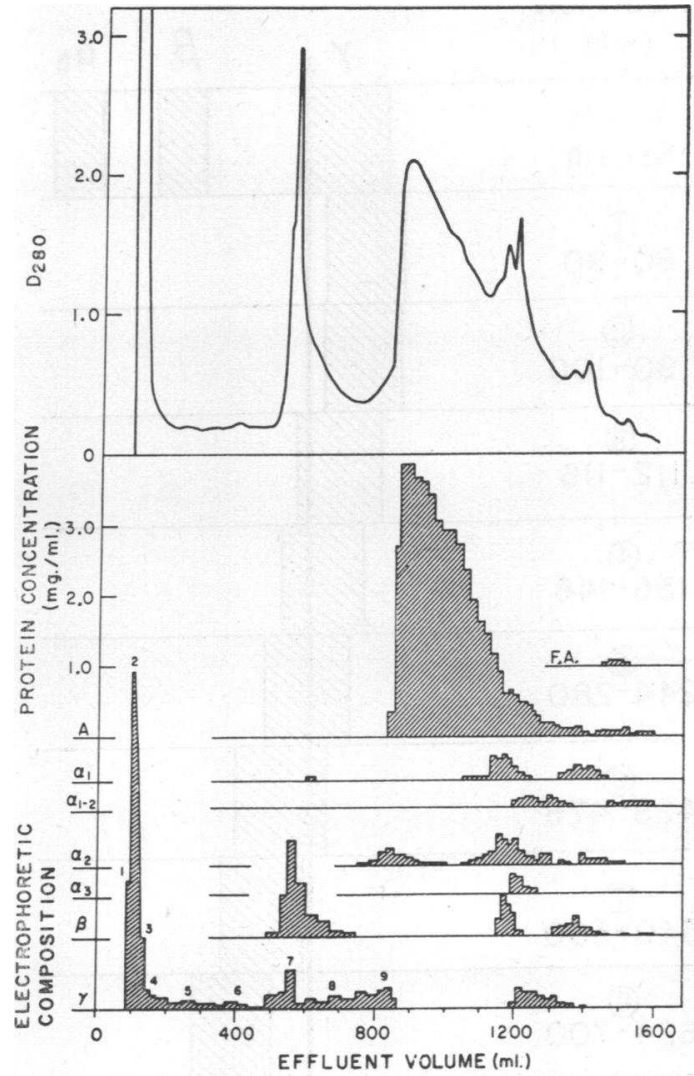

Fig. 2. Normal Serum Chromatogram: ElectroPHORETIC COMPOSITION

Chromatographic distribution of protein $\left(D_{280}\right)$ is represented in the upper half of the figure. The distribution of electrophoretic components is illustrated below. In each of the 66 chromatogram fractions the total protein content was measured by the biuret technique and the amount of each electrophoretic component was determined on the basis of the relative quantity found on paper electrophoresis. Each electrophoretic category (e.g., A, $\alpha$, $\alpha$ 1-2) is plotted from its own baseline. The scale of protein concentration is presented only from the albumin baseline but applies to all of the categories. F. A. refers to a component with an electrophoretic mobility fasterthan-albumin. Twenty $\mathrm{ml}$. of normal serum and the standard chromatographic procedure employing $16 \mathrm{Gm}$. of adsorbent, a flow rate of 20 to $25 \mathrm{ml}$. per hour., effluent collected in $4 \mathrm{ml}$. fractions, and gradient elution with $1,000 \mathrm{ml}$. of $0.01 \mathrm{M} \mathrm{pH} 8$ sodium phosphate buffer in the round flask and $500 \mathrm{ml}$. of $0.30 \mathrm{M}$ monosodium phosphate in the Erlenmeyer flask were utilized.

Among the last components to be eluted from the column is one that has the interesting property of migrating faster than albumin in an electric field (Figure 2). This component comprises 


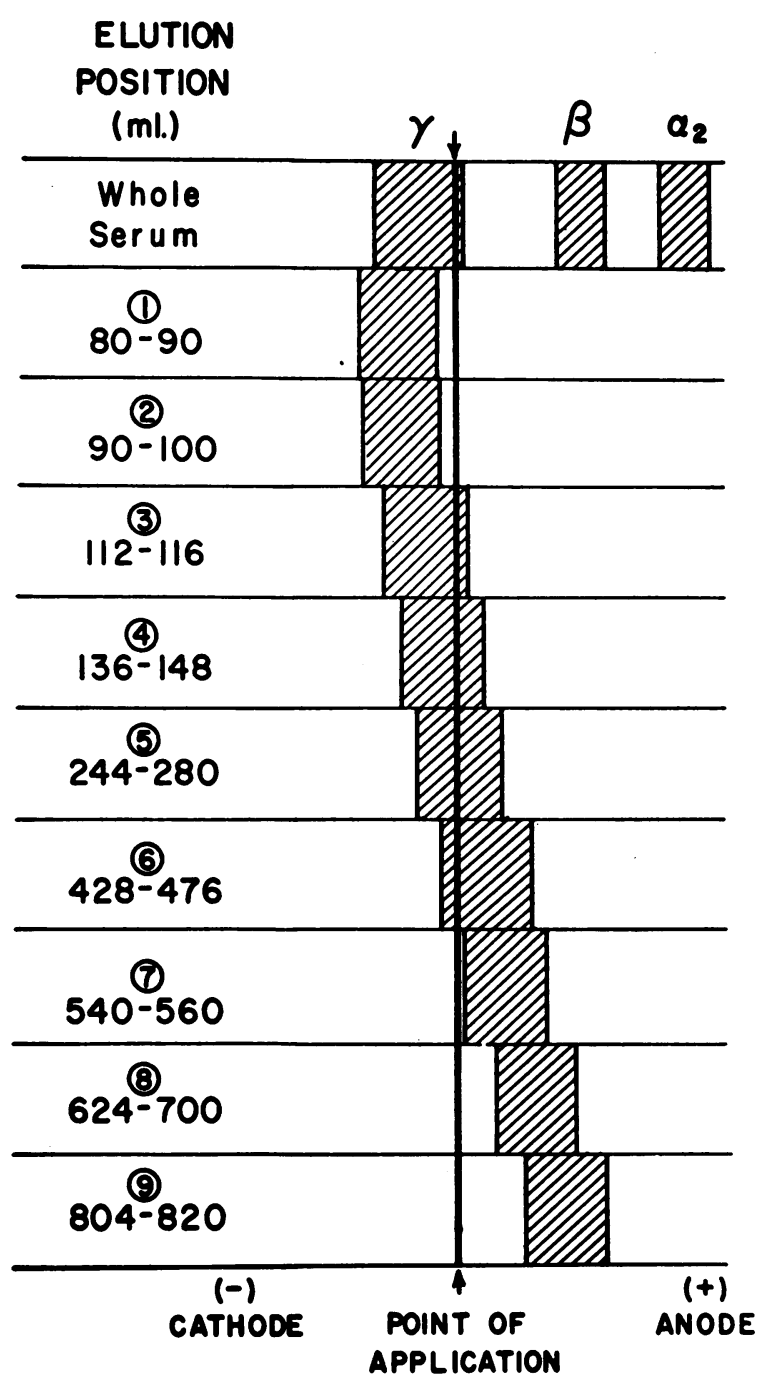

Fig. 3. Electrophoretic Characteristics of Serial Fractions Eluted in the First Part of the Chromatogram ("Gamma" Globulins)

The fraction sites are identified in Figure 2 as 1, 2, 3, et cetera. Electrophoresis was carried out on approximately $0.1 \mathrm{mg}$. of protein from each fraction, and the sequence of samples in the electrophoresis cell was randomized so that mobility progression could not be attributed to a procedural artifact.

about 0.1 to 0.2 per cent of the total protein applied to the column.

Colored protein bands are readily apparent on the column during chromatography, and three, sometimes four, pigmented regions are detectable in the effluent fractions. A pink color is noted in the 500 to $600 \mathrm{ml}$. region (Figure 2), corresponding to the distribution of the iron-binding protein.
If the serum contains appreciable hemoglobin, a red pigment will be detectable in the effluent just prior to albumin elution, suggesting the location there of the hemoglobin-haptoglobin complex $(16,5)$. Yellow pigments are seen in regions containing albumin. A blue component emerges in the region of $1,400 \mathrm{ml}$. and corresponds to the location of ceruloplasmin (2).

The $\mathrm{pH}$ and phosphate molarity of the effluent solutions are illustrated in Figure 4 for a $16 \mathrm{Gm}$. adsorbent chromatogram ( $20 \mathrm{ml}$. normal serum). These results provide a general picture of the conditions for protein adsorption and elution during chromatography, since a relatively fixed elution schedule was employed throughout these studies. ${ }^{5}$ A sharp fall in $\mathrm{pH}$ is noted to occur coincident with the appearance of the second major protein peak. This association is characteristic of the chromatographic procedure employed in these experiments. The conditions determining protein adsorption and elution from DEAE-cellulose columns have been discussed elsewhere $(1,17,18)$.

Representative results of the chromatography of 10,2 , and $1 \mathrm{ml}$. serum samples are illustrated in Figure 5. Also included in this figure are the results of electrophoretic examination of serial

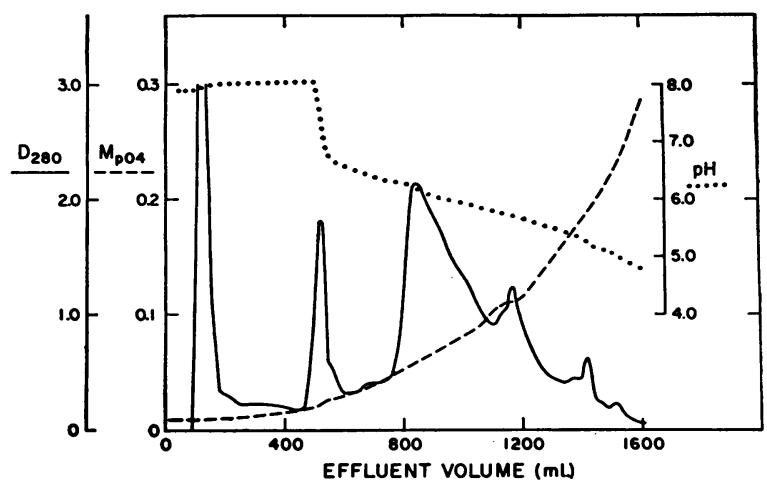

Fig. 4. Serum Chromatogram: pH and Molarity Changes in the Effluent

Normal serum $(20 \mathrm{ml}$.) was chromatographed. Protein distribution is indicated by the solid line, $\mathrm{pH}$ by the dotted line, and phosphate molarity by the broken line.

${ }^{5}$ In several of the chromatograms the relative level of the bottoms of the round and Erlenmeyer flasks was altered by a few millimeters with slight shift in component elution volume. This is most readily apparent with albumin. However, these minor changes are not thought to have significantly altered relative elution volumes. 
subdivisions of the $1 \mathrm{ml}$. serum chromatogram. Although component resolution appears to be reduced with the smaller columns, this is due at least partially to inability to reduce proportionately the volume of effluent fractions. Actually, the first alpha-2 component is better separated from albumin under the conditions employed on the 3 and $2 \mathrm{Gm}$. adsorbent columns.

For a $20 \mathrm{ml}$. serum sample, about three days were required for column elution, and the entire procedure from the drawing of the blood sample to determination of the protein concentration of the final chromatographic fraction can be carried out in five days by one person. For the chromatography of 2 and $1 \mathrm{ml}$. serum samples only 24 hours were needed for column elution and several samples could be chromatographed concurrently by one person.

Although the detail of resolution is reduced in the small scale chromatograms, unless the individual elution fractions are made inordinately small, a considerable saving in time and sample can be achieved by such modified procedures.

The conditions for chromatography utilized here are relatively mild, employing buffers with a $\mathrm{pH}$ range of 8.0 to 4.5 and molarity from 0.01 to $0.30 \mathrm{M}$. Several specific serum proteins, alkaline phosphatase, iron-, thyroxin-, and $\mathrm{B}_{12}$-binding protein, retained their specific functions and do not appear to have been altered by the chromatographic procedure.

\section{Protein-bound carbohydrate}

Most serum proteins contain some carbohydrate although the relative amount varies markedly among individual proteins (19). Protein-bound hexose has been measured in the effluent of eight serum chromatograms, and the findings in a representative normal chromatogram are illustrated in Figure 6.

At least five distinct peaks of hexose distribution are evident. The initial chromatographic peak, composed solely of gamma globulins, contained 1.2 per cent hexose, which agrees well with published data for the gamma globulins (20). The remaining carbohydrate peaks represent the composite hexose content of several electrophoretically distinct protein components. Further studies are underway to elucidate the distribution

\section{SERUM CHROMATOGRAPHY}

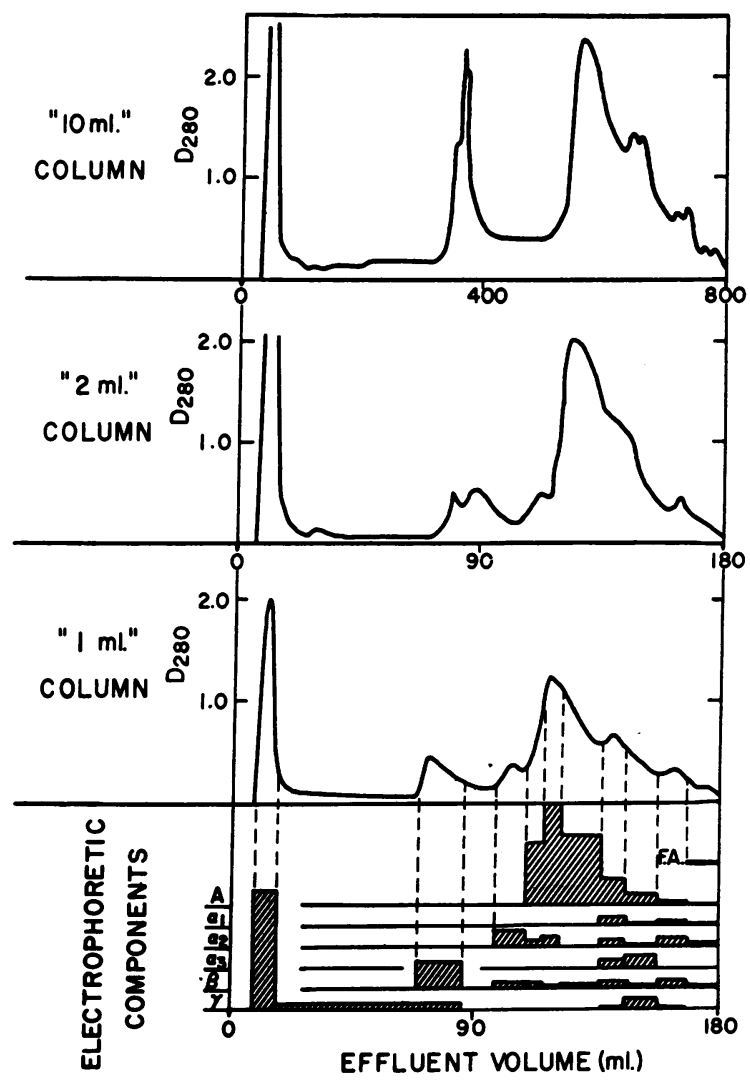

Fig. 5. Chromatography of 10,2 , and $1 \mathrm{ML}$. SERUM SAMPLES

Aliquots of a single sample obtained from a normal individual were employed. The conditions of chromatography are outlined in Table I. For the $2 \mathrm{ml}$. serum sample an eluting system of $110 \mathrm{ml}$. of $0.01 \mathrm{M} \mathrm{pH} 8$ phosphate buffer in the round flask, $55 \mathrm{ml}$. of $0.30 \mathrm{M}$ monosodium phosphate in the Erlenmeyer flask, and a $3 \mathrm{Gm}$. adsorbent column were utilized. Electrophoretic analysis of the $1 \mathrm{ml}$. serum chromatogram is also illustrated.

of hexose among these proteins in normal and pathologic sera.

In a previous study using related chromatographic procedures (2) orosomucoid and a high hexosamine content were found in a region corresponding to the peak at $1,370 \mathrm{ml}$. in Figure 6 . Hexosamine was also found in a region approximating the $550 \mathrm{ml}$. peak. The present studies emphasize the distribution of hexose among many serum components. Gamma globulin and at least four other chromatographic regions contribute to the total serum level. Since albumin is reported 

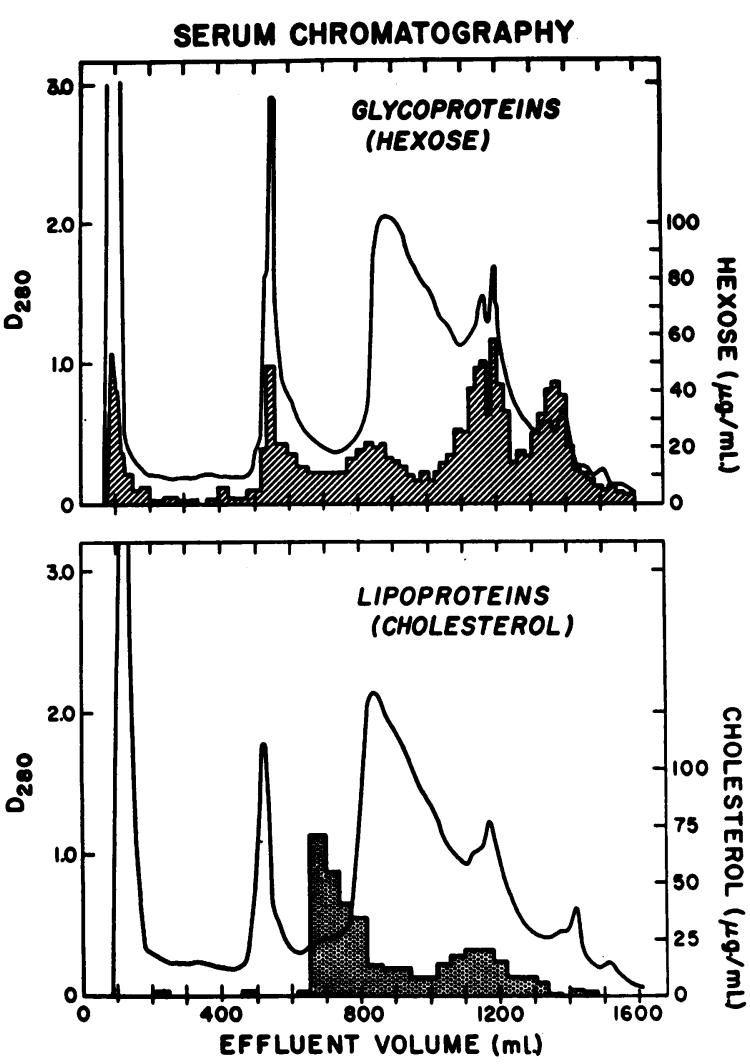

Fig. 6. Protein-Bound Carbohydrate (Hexose) and Cholesterol Distribution

Protein distribution $\left(D_{280}\right)$ is outlined by the solid line, and hexose and cholesterol distribution by the shaded areas. The $20 \mathrm{ml}$. serum samples employed for these chromatograms were obtained from two normal male donors.

to be free of carbohydrate (19), it should be noted that, although the carbohydrate level at the site of albumin elution is quite low ( 0.3 per cent), the finding of any carbohydrate here suggests the presence of protein components other than albumin which were not detected on electrophoretic analysis.

\section{Protein-bound cholesterol}

The chromatographic distribution of cholesterol-containing proteins is also illustrated in Figure 6. These lipoproteins are seen to be distributed among several regions in the chromatogram. More than one protein is present in these regions, and localization of the cholesterol with respect to electrophoretic and other categories remains to be done.

\section{Siderophilin}

Plasma iron is normally bound to a beta globulin referred to as siderophilin, iron-binding protein, or transferrin (21). The location of siderophilin in the chromatogram was ascertained by addition of radioactive iron to normal serum prior to chromatography. ${ }^{6}$ The similarity of distribution of radioactive iron and protein throughout the peak at 500 to $600 \mathrm{ml}$. is illustrated in Figure 7.

Electrophoretic examination of the chromatographic region containing the siderophilin revealed it to be composed primarily of a beta globulin ( 85 per cent), consistent with the known electrophoretic character of siderophilin. However, this region also contained a fast gamma electrophoretic component that comprised 15 per cent of the protein present. This "gamma" globulin constituted a variable minor proportion of the protein eluted in the 500 to $600 \mathrm{ml}$. region by the chromatographic procedure employed throughout this study. Recent refinements in technique have further improved the separation of siderophilin from gamma globulin (5). It should be noted that with the present chromatographic procedure the siderophilin is separated from much of the beta globulin which emerges later in the eluate.

\section{Vitamin $B_{12}$-binding protein}

The vitamin $B_{12}$ present in serum is largely bound to the serum proteins. In chronic myelocytic leukemia the serum $B_{12}$ level may be markedly elevated (22). Chromatography of serum from a patient with chronic myelocytic leukemia and a serum $B_{12}$ level 20 times normal is illustrated in Figure 7. The $\mathrm{B}_{12}$ activity is almost entirely confined to a single region in the latter third of the chromatogram. This region was further fractionated by electrophoretic techniques and the $B_{12}$ activity was located in an alpha globulin fraction. This has been confirmed in additional studies on similar sera (13).

The finding of $B_{12}$ in an alpha globulin fraction is in agreement with observations made by paper electrophoresis alone $(23,24)$. The use of chromatographic techniques in the present work has

\footnotetext{
${ }^{6}$ For assistance in this experiment we are greatly indebted to Drs. A. L. Schade, R. C. Woodworth, and J. M. Stengle.
} 
SERUM CHROMATOGRAPHY

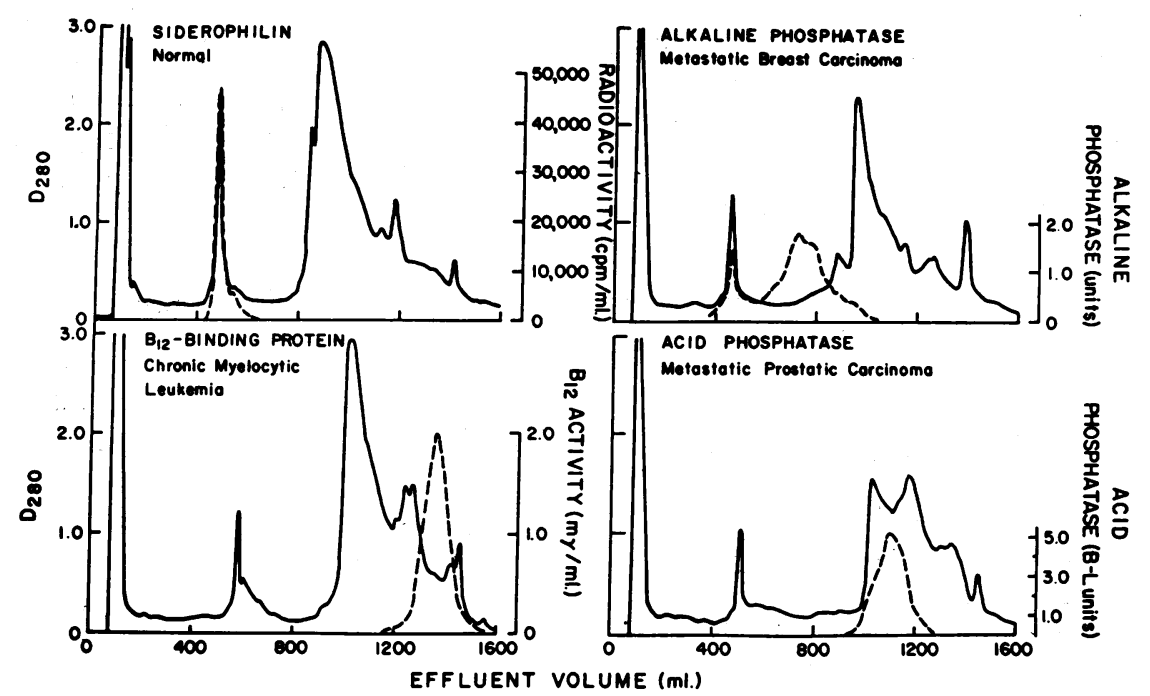

Fig. 7. Chromatographic Location of Siderophilin, B $_{12}$-Binding Protein, Alkaline and Acid Phosphatases

Protein distribution is represented by the solid line and special activities by broken lines. Amounts of dialyzed serum applied to the columns: siderophilin, $20 \mathrm{ml}$., with total protein of $6.5 \mathrm{Gm}$. per cent; $B_{12}$-binding protein, $18 \mathrm{ml}$, with total protein of $6.6 \mathrm{Gm}$. per cent and $B_{12}$ content of 12.0 millimicrograms per ml.; alkaline phosphatase, $20 \mathrm{ml}$., with total protein of $4.5 \mathrm{Gm}$. per cent and 22.5 units alkaline phosphatase per ml.; acid phosphatase, $19 \mathrm{ml}$., with total protein of $4.3 \mathrm{Gm}$. per cent and $43.2 \mathrm{~B}-\mathrm{L}$ acid phosphatase units per $\mathrm{ml}$.

permitted further separation of the $\mathrm{B}_{12}$-binding protein from several of the components which contribute to the alpha globulins. ${ }^{7}$

\section{Alkaline and acid phosphatases}

Alkaline and acid phosphatases, enzymatic activities normally present in the serum in small amounts, may be markedly increased with disease. Chromatography of serum having a high alkaline phosphatase activity, obtained from a patient with carcinoma of the breast and metastases to liver and bone, revealed the alkaline phosphatase activity to be largely distributed in two peaks (Figure 7 ). The possibility that these peaks might represent two different enzymes has been explored and confirmed in further studies carried out in collaboration with Dr. A. C. Peacock (25).

Chromatography of a serum with elevated acid phosphatase activity, obtained from a patient with

7 This study of the $B_{12}$-binding protein was conducted in collaboration with Drs. R. S. Mendelsohn and D. M. Watkin. metastatic prostatic carcinoma, is also illustrated in Figure 7. The distribution of acid phosphatase activity is seen to differ from that of alkaline phosphatase. This observation adds additional evidence indicating the separate identity of these enzymes. ${ }^{8}$

\section{Thyroxin-binding protein}

Circulating thyroxin has been found to be largely bound to a specific alpha globulin, referred to as the thyroxin-binding protein (26). The chromatographic location of the thyroxin-binding protein was determined by addition of an excess of radioiodine-labeled thyroxin to normal serum in vitro prior to dialysis and chromatography. ${ }^{\circ}$ Electrophoretic analysis of this labeled serum before chromatography revealed that the alpha thyroxin-binding protein contained 40 per cent of

8 The phosphatase observations were carried out in collaboration with Dr. A. C. Peacock.

${ }^{9}$ This study was carried out in collaboration with Dr. Jacob Robbins. 
the radioactivity and was saturated with thyroxin. The remaining 60 per cent of the radioactivity was associated with albumin. The results illustrated in Figure 8 demonstrate one principal peak of radioactivity. Further testing of 10 effluent fractions obtained throughout this region demonstrated that the radioactivity was nondialyzable and that on electrophoresis it was primarily confined to an alpha globulin fraction. Very little of the radioactivity was associated with albumin, and on completion of chromatography a considerable amount of radioactivity remained on the column. This material was eluted with $0.5 \mathrm{~N} \mathrm{NaOH}$ and found to be ultrafiltrable, and is presumed to have been thyroxin that originally was associated with albumin. The small peak of radioactivity seen near the end of the chromatogram was found on electrophoresis to be associated with the fasterthan-albumin components of this chromatographic region. It is not known whether this component is thyroxin or one of the nonthyroxin contaminants of the radioactive thyroxin preparation.

The elution schedule employed for this chromatogram differed from that utilized throughout the remainder of this study and achieved a moderate spreading of the components which compose the latter half of the usual chromatogram. It seems unlikely that the relative chromatographic location of the thyroxin-binding protein was al-

\section{SERUM CHROMATOGRAPHY: Thyroxin-binding Protein}

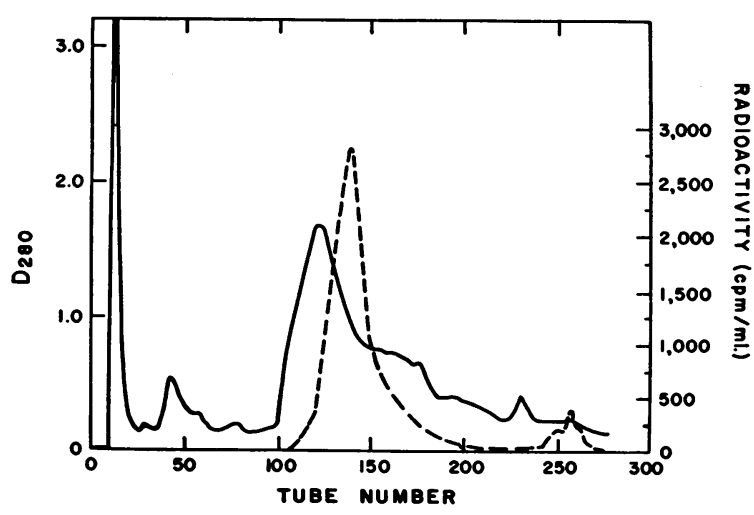

Fig. 8. Thyroxin-Binding Protein

Chromatogram obtained after addition of radioiodinelabeled thyroxin to normal serum. Protein distribution is indicated by the solid line and radioactivity by the broken line. The elution schedule employed for this chromatogram was not the usual one and is outlined under the Methods section. tered by this modification in procedure. The finding of thyroxin bound to an alpha-globulin confirmed results obtained by electrophoretic techniques alone (15), and, in addition, a further separation of thyroxin-binding protein from a portion of the other alpha globulin components was achieved.

\section{Radioiodine-labeled albumin}

Radioactive iodine-labeled human serum albumin (RISA) was added to normal serum prior to dialysis and chromatography. ${ }^{10}$ This iodinated albumin is available commercially and is commonly used in this country for observations on the physiology of human serum albumin (27). However, as is seen in Figure 9, the chromatographic distribution of the radioactive albumin did not correspond to that of the bulk of the serum albumin.

Further examination of the effluent revealed that the radioactivity was not dialyzable and was associated only with albumin when electrophoresis was performed on the regions of the chromatogram containing radioactivity. The results indicate that the radioactive albumin was not representative of the native serum albumin, at least in

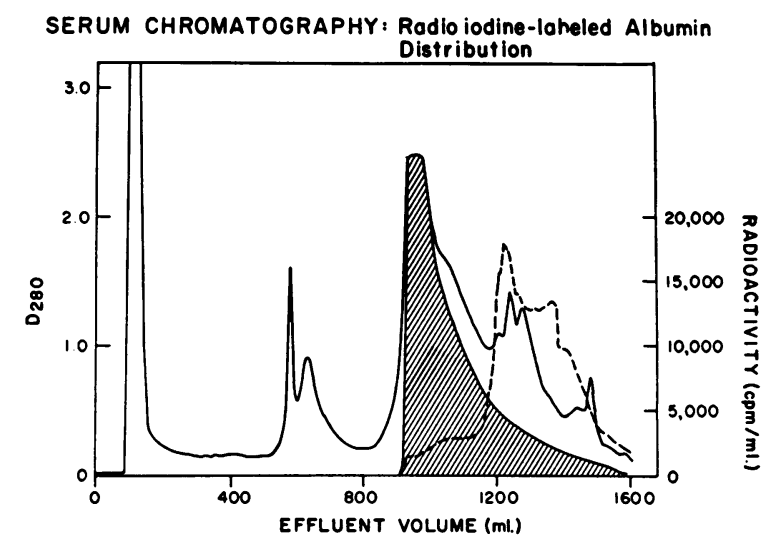

Fig. 9. Radioiodinated Albumin

One mg. of iodinated albumin (20 $\mu \mathrm{c}$. of $\left.\mathrm{I}^{121}\right)$ was added, prior to dialysis, to $27 \mathrm{ml}$. of fresh normal human serum containing $961 \mathrm{mg}$. of albumin, and $20 \mathrm{ml}$. of the dialyzed serum was chromatographed. The protein distribution in the chromatogram is indicated by the solid line, the albumin distribution by the shaded area, and the distribution of radioactivity (iodinated albumin) by the broken line.

${ }^{10}$ This study was carried out in collaboration with Dr. J. L. Steinfeld. 


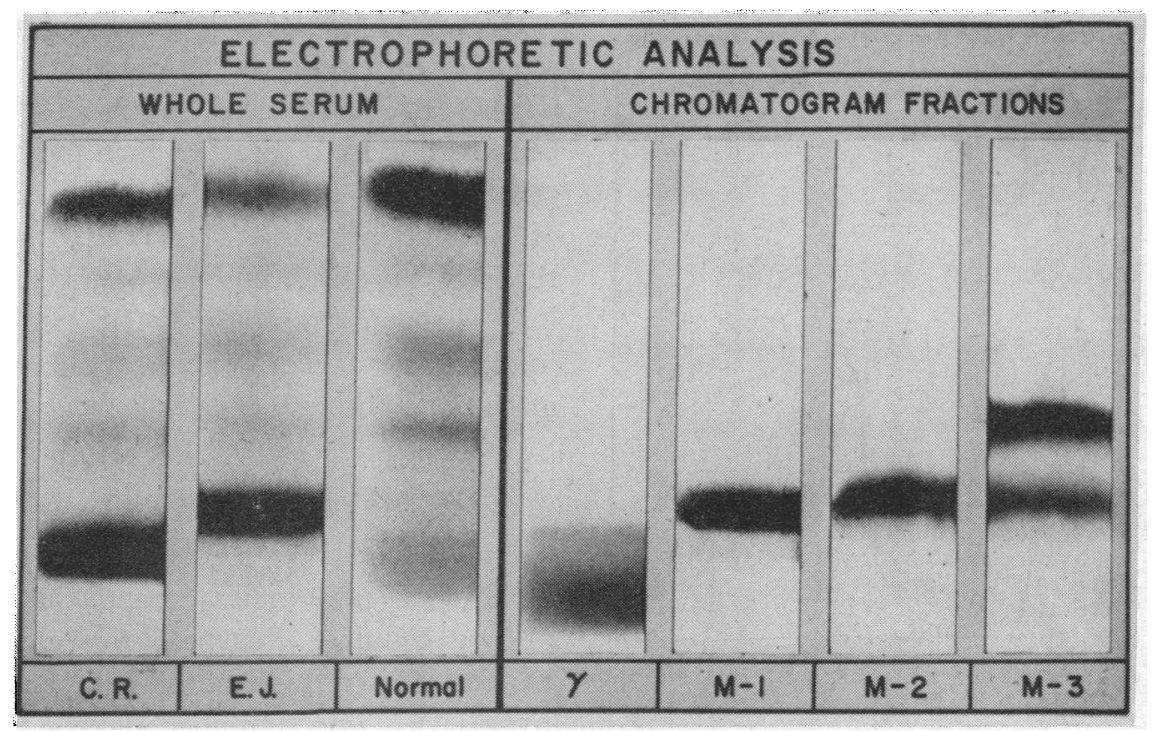

Fig. 10. Paper Electrophoretic Patterns of Multiple Myeloma Sera and Chromatogram Fractions

The paper electrophoretic patterns are arranged so that albumin is seen at the upper (anodal) end of the normal serum strip and gamma globulin at the lower end. Electrophoretic analysis of the first four E. J. chromatogram peaks are included.

regard to behavior during column chromatography. This difference is of interest because of the large amount of information obtained in recent years on the biological behavior of iodinated albumin and the general inference from these studies as to the biological characteristics of native albumin.

The present studies do not indicate whether the difference in chromatographic distribution of the native serum albumin and the iodinated albumin resulted from changes induced during preparation or during "pasteurization" of the albumin, by selective iodination of a distinctive group of albumin molecules, by the presence of iodine on the tyrosine residues of albumin, by the oxidation procedure used to achieve iodination, or by the effects of radioactivity on the albumin molecules. Further studies are underway to elicit this information.

\section{Myeloma protein}

Sera from two patients with multiple myeloma were selected for chromatographic analysis. Both sera on electrophoretic examination demonstrated large amounts of a homogeneous protein having a gamma mobility (Figure 10). The chromato- graphic results, illustrated in Figure 11, demonstrate that in both instances the abnormal protein emerged from the column near the region where most of the normal gamma globulin appear. No abnormal protein was discerned in the later parts of the chromatogram. A diminished peak in the albumin region corresponded to the lowered serum albumin seen on electrophoresis. It is noteworthy that the myeloma protein patterns of the $C$. $R$. and E. J. serum chromatograms suggest the presence of several components. This is particularly evident in the E. J. serum. Chromatographic analysis was repeated on both sera with similar results. Serial electrophoretic examination of the myeloma regions from the E. J. chromatogram is recorded in Figure 10. There was no evidence of electrophoretic distinction among the several chromatographic peaks.

Of particular interest in the serum chromatogram of $\mathrm{E}$. J. was the observation of a small protein peak at the site of normal gamma globulin elution. Electrophoretic examination of this peak revealed a qualitatively normal gamma globulin pattern without evidence of any abnormal component (Figure 10). The adjacent $M$ peak, however, was found to consist of electrophoretically 
SERUM CHROMATOGRAPHY: Multiple Myeloma

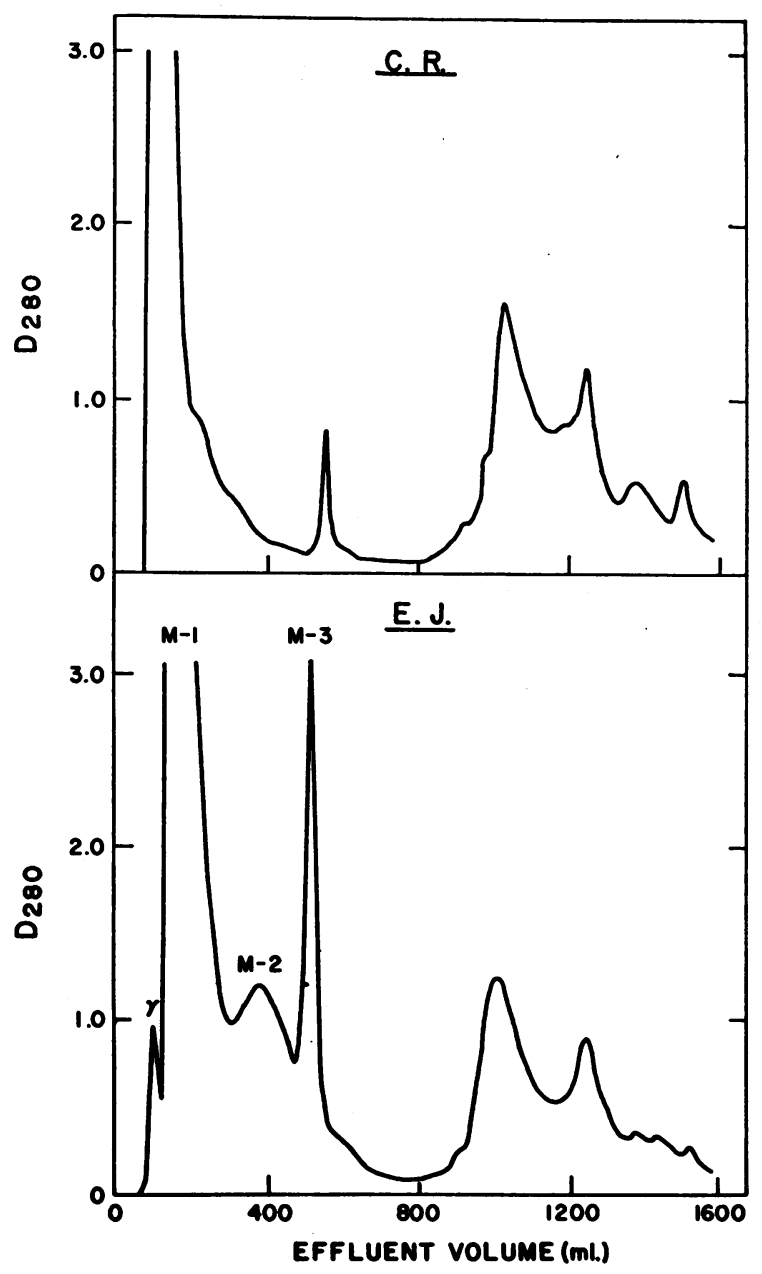

Fig. 11. Multiple Myeloma

Sera from two subjects with multiple myeloma were chromatographed in the usual way. The large amount of protein eluted in the initial portion of the chromatogram could not be included within the limits of this scale.

homogeneous protein of narrow distribution that was characteristic of the myeloma protein seen in the whole serum. Gamma globulin was not evident in this chromatographic component. The chromatographic separation of "normal" gamma globulin from myeloma protein in the E. J. serum was improved on further chromatographic study by using a starting buffer of lower molarity $(0.005 \mathrm{M})$. In the C. R. serum the myeloma protein began to emerge at the same site as normal gamma globulin and no distinction could be made chromatographically between normal gamma globulin and the initial myeloma protein peak.
Decreased levels of gamma globulin have been reported previously in patients with multiple myeloma (28). However, these observations have been restricted to sera in which the electrophoretic gamma region was not obscured by a large amount of myeloma protein. The chromatographic results reported here indicate that anion-exchange cellulose chromatography may be useful in certain instances for the evaluation of the serum proteins of patients with multiple myeloma.

\section{DISCUSSION}

The demonstration that the serum proteins can be divided into many components by anion-exchange cellulose chromatography suggests many applications of this technique in the study of proteins (2). The simplified method presented here has preserved most of the resolving capacity of the DEAE-cellulose column while making the procedure more suitable for clinical studies. The chromatographic and analytic results reported here are in essential agreement with the earlier observations on the application of ion-exchange cellulose chromatography to human serum (2).

Fractionation of the serum electrophoretic categories is one of the most interesting characteristics of DEAE-cellulose chromatography (2). Subdivision of alpha and beta globulins is readily apparent. In the present study fractionation of the serum glycoproteins and lipoproteins has been demonstrated. The beta iron-binding globulin and the beta lipoproteins have been separated chromatographically. The determination of siderophilin distribution by means of a radioactive iron preparation also confirms results obtained by a spectrophotometric technique (2). Among the alpha globulin subdivisions the thyroxin-binding protein, vitamin $\mathrm{B}_{12}$-binding protein and ceruloplasmin have been identified. Acid and alkaline phosphatases in pathologic serum have also been separated by Boman and Westlund (4) who employed anion-exchange chromatography on columns of Dowex-2 resin. This resin, however, has a low capacity for proteins when compared with DEAE-cellulose (1).

Albumin also appears to be fractionated by anion-exchange cellulose chromatography. Previous immunologic and electrophoretic studies of albumin fractions obtained by chromatographic 
separation suggested differences between the albumins of several fractions (2). The chromatographic distribution of the radioiodinated albumin preparations that have been tested differed markedly from the distribution of the bulk of native serum albumin.

The composition and significance of the fasterthan-albumin component is unknown at present. Hoch and Chanutin observed such a component, and in about the same concentration, on electrophoresis of normal undialyzed plasma in $0.1 \mathrm{M}$ $\mathrm{NaCl}$ at $\mathrm{pH} 8$ (29).

Tiselius, Hjerten, and Levin (3) have reported fractionation of human gamma globulin and of bovine serum albumin on calcium phosphate columns, and Porter utilized celite columns to fractionate the immune proteins among the gamma globulins (30). Cation-exchange cellulose columns have also been employed to fractionate human gamma globulin (31). These reports and the findings with anion-exchange cellulose chromatography serve to reemphasize the heterogeneity of materials normally present in the serum electrophoretic compartments.

Chromatographic analysis has been performed on many individual normal sera and also on sera obtained from patients with a variety of diseases. The chromatographic patterns of the pathologic sera were frequently abnormal. Chromatograms of pathologic sera obtained from patients with chronic myelocytic leukemia, carcinoma of the breast, carcinoma of the prostate and multiple myeloma are presented. In several instances the initial (gamma) peak was increased or decreased, the peaks containing siderophilin and albumin were decreased, and the regions containing ceruloplasmin and the alpha glycoproteins were increased.

These findings, although preliminary, suggest that anion-exchange cellulose chromatography may have considerable value as an analytic procedure, in addition to its evident usefulness in protein fractionation. The potentialities of chromatography as an analytic procedure are perhaps best illustrated in the present report by the observations on radioiodinated albumin and myeloma protein distribution. Whether myeloma serum will yield characteristic chromatograms distinctly different from those found with sera containing markedly elevated gamma globulins of other etiology remains to be seen. However, the demonstration that in certain instances the myeloma protein may be separable from the "normal" gamma globulins does indicate that anion-exchange cellulose chromatography may be useful for the quantification of the "normal" gamma globulins present in this disease.

\section{SUMMARY}

A modified anion-exchange (DEAE-) cellulose chromatographic procedure for the separation and characterization of serum proteins is described. This procedure has been applied to serum samples of $20,10,2$, and $1 \mathrm{ml}$.

The chromatographic fractions of normal serum were characterized by electrophoresis and by carbohydrate and cholesterol content. The usual serum electrophoretic components have been subdivided into several fractions by this chromatographic procedure, and a faster-than-albumin component has been regularly uncovered. The chromatographic distribution of siderophilin (ironbinding protein), thyroxin-binding protein, $\mathrm{B}_{12}-$ binding protein, and acid and alkaline phosphatases was determined. These components were separated on the chromatogram from many proteins of similar electrophoretic mobility. The chromatographic distribution of radioiodinated human serum albumin was found to differ significantly from the distribution of native serum albumin.

Chromatograms of serum obtained from patients with chronic myelocytic leukemia, carcinoma of the breast, prostatic carcinoma, and multiple myeloma are presented. Several of these differed markedly from the normal chromatograms. In one instance the myeloma protein appeared to be separable from most of the normal gamma globulin. The significance of these observations is discussed.

\section{ACKNOWLEDGMENTS}

The authors wish to thank Drs. Herbert A. Sober and Elbert A. Peterson whose generous and frequent assistance made this study possible, and Miss Ann P. Horbett for help with the electrophoretic analyses.

\section{REFERENCES}

1. Peterson, E. A., and Sober, H. A. Chromatography of proteins. I. Cellulose ion-exchange adsorbents. J. Amer. chem. Soc. 1956, 78, 751. 
2. Sober, H. A., Gutter, F. J., Wyckoff, M. M., and Peterson, E. A. Chromatography of proteins. II. Fractionation of serum protein on anion-exchange cellulose. J. Amer. chem. Soc. 1956, 78, 756.

3. Tiselius, A., Hjerten, S., and Levin, O. Protein chromatography on calcium phosphate columns. Arch. Biochem. 1956, 65, 132.

4. Boman, H. G., and Westlund, L. E. Protein chromatography on an anion-exchange resin. Arch. Biochem. 1956, 64, 217.

5. Peterson, E. A., and Sober, H. A. Personal communication.

6. Gornall, A. G., Bardawill, C. J., and David, M. M. Determination of serum proteins by means of the biuret reaction. J. biol. Chem. 1949, 177, 751.

7. Lever, W. F., Gurd, F. R. N., Uroma, E., Brown, R. K., Barnes, B. A., Schmid, K., and Schultz, E. L. Chemical, clinical, and immunological studies on the products of human plasma fractionation. XL. Quantitative separation and determination of the protein components in small amounts of normal human plasma. J. clin. Invest. 1951, 30, 99.

8. Williams, F. G., Jr., Pickels, E. G., and Durrum, E. L. Improved hanging-strip paper electrophoresis technique. Science 1955, 121, 829.

9. Jencks, W. P., Jetton, M. R., and Durrum, E. L. Paper electrophoresis as a quantitative method. Biochem. J. 1955, 60, 205.

10. Shetlar, M. R., and Masters, Y. F. Use of thymolsulfuric acid reaction for determination of carbohydrates in biological material. Analyt. Chem. 1957, 29, 402.

11. Abell, L. L., Levy, B. B., Brodie, B. B., and Kendall, F. E. A simplified method for the estimation of total cholesterol in serum and demonstration of its specificity. J. biol. Chem. 1952, 195, 357.

12. Schade, A. L., Oyama, J., Reinhart, R. W., and Miller, J. R. Bound iron and unsaturated ironbinding capacity of serum; rapid and reliable quantitative determination. Proc. Soc. exp. Biol. (N. Y.) 1954, 87, 443

13. Mendelsohn, R. S., Watkin, D. M., Horbett, A. P., and Fahey, J. L. Identification of the vitamin $B_{12}$ binding protein in the sera of normals and of patients with chronic myelocytic leukemia. In preparation.

14. Bessey, O. A., Lowry, O. H., and Brock, M. J. A method for the rapid determination of alkaline phosphatase with five cubic millimeters of serum. J. biol. Chem. 1946, 164, 321.

15. Robbins, J. Reverse-flow zone electrophoresis. A method for determining the thyroxine-binding capacity of serum protein. Arch. Biochem. 1956, 63, 461.
16. Jayle, M. F., Boussier, G., and Badin, J. Electrophorèse de l'haptoglobine et de son complexe hémoglobinique. Bull. Soc. Chim. biol. (Paris) 1952, 34, 1063.

17. Moore, S., and Stein, W. H. Column chromatography of peptides and proteins. Advanc. Protein Chem. 1956, 11, 191.

18. Sober, H. A., and Peterson, E. A. Chromatography of proteins and nuclei acids in Ion Exchangers in Organic and Biochemistry, C. Calmon and T. R. E. Kressman, Eds. New York, Interscience Publishers, 1957, p. 318.

19. Hughes, W. L. Interstitial proteins: The proteins of blood plasma and lymph in The Proteins, $\mathbf{H}$. Neurath and K. Bailey, Eds. New York, Academic Press Inc., 1954, vol. II, p. 663.

20. Müller-Eberhard, H. J., and Kunkel, H. G. The carbohydrate of $\gamma$-globulin and myeloma proteins. J. exp. Med. 1956, 104, 253.

21. Laurell, C.-B. Plasma iron and the transport of iron in the organism. Pharmacol. Rev. 1952, 4, 371.

22. Beard, M. F., Pitney, W. R., and Sanneman, E. H. Serum concentrations of vitamin $B_{12}$ in patients suffering from leukemia. Blood 1954, 9, 789.

23. Pitney, W. R., Beard, M. F., and Van Loon, E. J. Observations on the bound form of vitamin $B_{12}$ in human serum. J. biol. Chem. 1954, 207, 143.

24. Heinrich, H. C., and Erdmann-Oehlecker, S. Der Vitamin $B_{12}$-Stoff wechsel bei Hämoblastosen. II. Die intravitale Bindung (Transport) der $\mathrm{B}_{12}$-Vitamine an die Serumproteinfraktionen bei Hämoblastosen. Clinica chim. Acta 1956, $1,311$.

25. Peacock, A. C., and Fahey, J. L. Demonstration of two alkaline phosphatase activities in normal and pathologic sera. In preparation.

26. Robbins, J., and Rall, J. E. Interaction of thyroid hormones and proteins in biological fluids in Recent Progr. Hormone Res. In press.

27. The role of $I^{121}$ labeled proteins in biology and medicine, S. P. Masouredis, Ed. Ann. N. Y. Acad. Sci. 1957, 70, pp. 1-152.

28. Adams, W. S., Alling, E. L., and Lawrence, J. S. Multiple myeloma: Its clinical and laboratory diagnosis with emphasis on electrophoretic abnormalities. Amer. J. Med. 1949, 6, 141.

29. Hoch, H., and Chanutin, A. Electrophoretic studies on fast moving components of human serum. J. biol. Chem. 1953, 200, 241.

30. Porter, R. R. Fractionation of rabbit gamma-globulin by partition chromatography. Biochem. J. 1955, 59, 405.

31. Sober, H. A., and Peterson, E. A. Chromatography of proteins on modified cellulose. Vox Sang. (Basel) 1957, 2, 62. 